\title{
Interaksi Politik Jawara dalam Pembangunan Perspektif Tindakan Komunikatif
}

https://doi.org/10.25008/wartaiski.v2i02.40

\author{
Neka Fitriyah ${ }^{1}$, Sarwititi Sarwoprasodjo ${ }^{2}$, Sofyan Sjaf $^{3}$, Endriatmo Soetarto ${ }^{4}$ \\ ${ }^{1}$ Program Studi Komunikasi Fisip Universitas Sultan Ageng Tirtayasa \\ Jl. Raya Jakarta Km 4, Panancangan, Kec. Cipocok Jaya, Kota Serang, Banten 42124 - \\ Indonesia \\ ${ }^{2}$ Program Studi Komunikasi Pembangunan Pertanian dan Perdesaan Institut Pertanian Bogor \\ ${ }^{3,4}$ Program Studi Sosiologi Pedesaan Perdesaan Institut Pertanian Bogor \\ ${ }^{2,3,4} \mathrm{Jln}$. Kamper Kampus IPB, Dramaga-Bogor 16620 - Indonesia \\ Email korespondensi:neka_fitriyah@untirta.ac.id
}

\begin{abstract}
Abstrak
Jawara sebagai elite lokal di Pandeglang merupakan kekuatan kultural yang memiliki otoritas dalam menentukan sikap dan perilaku politik masyarakat. Aktivitas komunikasi Jawara dalam politik mengarah pada upaya-upaya dalam membangun konsensus politik. Karena kepentingan ini, tidak sedikit Jawara terjebak pada persoalan-persoalan pragmatis. Permasalahan ini kemudian menjadi krusial karena kesahihan dan validitas pesan yang disampaikan Jawara dalam membangun konsesnus politik memberi corak tersendiri dan dampak bagi pembangunan. Pendekatan teknokrasi, paternalistik dan clientism di Pandeglang mengakibatkan kesahihan dan validitas pesan yang disamapaikan sulit terwujud karena cenderung dipenuhi oleh praktik marginalisasi. Tujuan penelitian ini adalah (1) mengkonstruksi interaksi politik Jawara dalam pembangunan; (2) mendekatkan persoalan interaksi politik Jawara dalam perspektif teori tindakan komunikatif. Penelitian ini menggunakan metode kualitatif dengan paradigma konstruktivis. Pengamatan dilakukan pada level makro dan mikro, interaksi politik diamati baik dalam aktvitas politik informal maupun aktivitas politik formal yang didominasi oleh Jawara. Kesimpulan penelitian ini adalah: (1) konstruksi dari interaksi politik Jawara dalam pembangunan belum memberikan manfaat sepenuhnya terhadap pembangunan dan kesejahteraan masyarakat Banten; (2) teori tindakan komunikatif dalam penelitian ini tidak bisa secara an sich melihat pembangunan dalam konteks tujuan dari tindakan komunikatif itu sendiri tetapi perlu juga disandingkan dengan realitas struktur dan kultur masyarakat.
\end{abstract}

Kata kunci: Elite, Jawara, Tindakan Komunikatif.

\begin{abstract}
Jawara as a local elite in Pandeglang is a cultural force that has authority in determining the political attitudes and behavior of the community. Communication activities Jawara in politics lead to efforts in building political consensus. Because of this interest, not a few Jawara are stuck on pragmatic issues. This problem then becomes crucial because the validity and the validity of the message conveyed by Jawara in developing a political consensus gives its own style and impact on development. The technocracy, paternalistic and clientism approaches in Pandeglang resulted in the validity and validity of the messages that were conceived difficult to realize because they tended to be filled with marginalization practices. The purpose of this study is (1) constructing Jawara political interaction in development (2) bringing the issue of Jawara political interaction closer in the perspective of the theory of communicative action. This study uses qualitative methods with constructivist paradigms. Observations were made at the macro and micro levels, political interactions were observed both in informal political activities and informal political activities dominated by Jawara. The conclusions in this study are that (1) the construction of the Jawara political interaction in development has not provided full benefits to the development and welfare of the Banten community (2) the theory of communicative action cannot see development in the context of the purpose of the communicative action itself but it also needs to be juxtaposed with the reality of the structure and culture of society.
\end{abstract}

Keywords: Elite, Jawara, Communicative Actions. 


\section{PENDAHULUAN}

Era reformasi telah mengantarkan dinamika politik pada era baru dimana aktor politikinstitusi-budaya lokal bermunculan kembali dan mulai berperan kembali dalam praktik politik lokal. Aktor-aktor lokal menjadi lebih teroganisir dan semakin menunjukan kekuatan identitas serta simbol kulturalnya sehingga kembali memiliki kesempatan dalam lingkaran politik. Atas fenomena ini, Kolopaking (2011) memberikan pandangan bahwa pengorganisasian, pendistribusian politik yang tidak tepat atas keberadaan kelompok, suku bangsa "identitas" yang sangat beragam di era desentralisasi berimplikasi pada potensi konflik yang kerap muncul baik di perdesaan maupun perkotaan.

Realitas empirik yang terjadi di era desentaralisasi ini kemudian memunculkan ketimpangan pembangunan, yang mengarah pada ketimpangan antar kelompok masyarakat dalam satu provinsi. Di sisi lainnya, ketimpangan pembangunan disebabkan pula oleh model-model komunikasi pembangunan yang cenderung mermarjinalkan aspirasi masyarakat (Servaes, 2002). Temuan yang menarik dari Hidayat Syarief dan Gismar (2007) menjelaskan bahwa persoalan disintegrasi yang menjamur di Indonesia lebih disebabkan karena ketimpangan yang terjadi antar kelompok dalam provinsi, antar daerah, antar Jawa luar Jawa dan atau antar Provinsi.

Banten adalah sebagai salah satu dari lima Provinsi baru selain Gorontalo, Maluku Utara, Kepulauan Riau yang dibentuk setelah diberlakukan UU No 22 dan 25/1999. Sebagai provinsi pertama yang dibentuk, Banten merupakan "pembuka jalan" bagi pemekaran provinsi lainnya. Sejalan dengan ditetapkannya UU No 23/2000, Banten kemudian diresmikan menjadi provinsi dan terpisah dari Jawa Barat pada Oktober 2000. Sedangkan Kabupaten Pandeglang merupakan salah satu dari Kabupaten yang ada di wilayah Provinsi Banten yang secara sosiologis dan kultural memiliki kekhasan dan kekhususan tersendiri.

Lebih dari sepuluh tahun perjalanan desentralisasi dan otonomi daerah di Provinsi Banten berlangsung, patut diakui bahwa desentralisasi dan otonomi daerah telah banyak memberikan berbagai dampak positif juga dampak negatif bagi Kabupaten Pandeglang. Dibalik dampak positif yang telah diberikan (seperti: kebebasan pers, kebebasan berpendapat, menyampaikan kritik, inovasi, teknologi dan kreativitas pemerintah daerah dalam melakukan tata kelola pemerintah), tidak sedikit desentralisasi juga menimbulkan dampak negatif, seperti ketimpangan pembangunan, dominasi politik, praktik KKN (korupsi, kolusi dan nepotisme) dan menjamurnya politik clientism yang memarginalkan keberadaan masyarakat. Sjaf (2014) menemukan dampak negatif tersebut mempertegas bahwa kebijakan desentralisasi dan otonomi daerah menjadi pintu masuk kebangkitan politik lokal yang menempatkan dominasi etnisitas tertentu terhadap etnisitas lainnya dalam berbagai arena.

Jawara sebagai etnisitas lokal di Pandeglang merupakan kekuatan yang memiliki otoritas dalam menentukan sikap dan perilaku politik masyarakat. Hal ini dikarenakan bukan saja karena kedudukan, jabatan politik Jawara tetapi lebih karena, kharisma, mitos yang melekat atau karena pengetahuan serta pengalaman yang dimilikinya (Karaomani 2008). Kedudukan yang istimewa ini membuat masyarakat Banten cenderung menitipkan, menyerahkan dan mewakilkan kepentingan serta aspirasinya pada Jawara. Hal inilah kemudian yang memicu tumbuh kembangnya organisasiorganisasi kelembagaan Jawara baik di tingkat Provinsi, Kabupaten-Kota di Provinsi Banten juga sebaran politik Jawara dalam berbagai partai politik juga lembaga swadaya masyarakat.

Tumbuh suburnya kekuatan Jawara baik kelembagaan formal maupun informal serta dalam interaksi keseharian menjadikan Jawara sangat leluasa melakukan interaksi politik dan terjebak dalam romantisme politik praktis. Dalam frame politik, Jawara kemudian secara intensif melakukan interaksi politik baik dengan pemerintah, partai politik dan masyarakat dalam membangun konsensus. Interaksi politik formal (yang dilakukan melalui jalur-jalur organisasi formal) Jawara ditujukan untuk membangun kesahihan pesan, tetapi dalam praktiknya tidak sedikit interaksi politik Jawara yang lebih mengutamakan kepentingan pribadi dan kelompok (politik pragmatis), sehingga mengalami proses komunikasinya mengalami distorsi. Senada dengan temuan dari Armuji \& Pratikno (2004) interaksi politik Jawara dalam praktiknya kental dengan muatan-muatan pragmatis. 
e-ISSN: 2686-0724 - p-ISSN: 0853-4470 - Vol. 02, No. 02 (2019), pp. 104-116

Implikasi dari pragmatisme politik Jawara ini, berakibat pada kesahihan pesan yang berdampak pada transformasi peran Jawara secara besar-besaran. Untuk kepentingan praktis dan pragmatis ini Jawara banyak yang bertransformasi menjadi politisi, birokrat dan pengusaha, Hidayat et al (2007). Transformasi ini kemudian semakin memudahkan interaksi politik Jawara dalam kepentingan praktis tersebut (Muslim et al 2015). Persoalannya kemudian adalah apakah interaksi politik Jawara berdampak bagi terbukanya dialog-dialog dan tumbuh kembangnya ruang-ruang publik yang kemudian mendorong tindakan komunikatif dan upaya kritis masyarakat untuk mendapatkan keadilan sosial, kesejahteraan sosial dan terlibat dalam pembangunan.

Proposisi utama dalam penelitian ini adalah kesahihan dan validitas pesan sebagai syarat tindakan komunikatif dalam interaksi politik Jawara dipengaruhi berbagai kepentingan-kepentingan politik pragmatis. Implikasinya adalah Jawara sulit sekali mencapai konsesnsus dan mendapatkan legitimasi dari masyarakat. Dalam perspektif tindakan komunikatif, hal ini menandakan bahwa interaksi politik Jawara telah gagal mengantarkan masyarakat Pandeglang dalam mencapai kesadaran kritis dan keadilan sosial dalam pembangunan. Pembicaraan politis, argument dan manuver politik Jawara mengindikasikan telah terjadi ketidak percayaan masyarakat, terjadi diskoneksi dan gap kepentingan antara masyarakat dan Jawara sehingga validitas, konsesnus dan legitimasi pesan sulit sekali dibangun.

Berdasarkan realitas permasalahan inilah interaksi komunikasi politik Jawara dalam pembangunan menjadi sangat menarik dan unik, terlebih, akar persoalan interaksi politik Jawara itu sendiri berhubungan dengan perkembangan kondisi politik lokal di Kabupaten Pandeglang dimana Jawara menjadi faktor determinan terhadap peta pembangunan dan politik lokal.

Beberapa temuan yang melatarbelakangi perumusan masalah ini diantaranya: Pertama, pembangunan dan politik lokal pada praktiknya menyuburkan tumbuh kembangnya elite lokal, (Pribadi 2015). Kedua, pembangunan dalam perekembangannya cenderung menghegemoni, sehingga masyarakat secara politis mudah terkooptasi, termarginalkan dan termiskinkan (Nurdholth HS, Klinken 2007). Ketiga, politik lokal, pembangunan daerah dan politik dinasti pada beberapa sisi semakin mengaburkan makna dan prinsip-prinsip demokrasi, Sujarwoto (2015). Keempat, komunikasi politik dalam praktiknya banyak melakukan tindakan a demokratis yang berimplikasi pada margnalisasi masyarakat (Antonius Galih Prasetyo 2012). Kelima, tindakan komunikatif merupakan praktik komunikasi dan interaksi masyarakat yang harus didorong dalam ruang-ruang publik, Amal (2015). Keenam, elite lokal dalam praktik politik dan pembangunan cenderung menggunakan kekuasaan dan kekerasan untuk kepentingan kelompoknya (Rozaki 2009).

Temuan-temuan di atas secara tidak langsung mencoba mengantarkan fenomena bahwa keberadaan Jawara sebagai elite lokal di Pandeglang dan perannya dalam pembangunan, memperkuat keberadaan kelompok-kelompok kepentingan. Jawara sebagai elite lokal di Pandeglang misalnya, berperan sebagai opinion leader, informal leader dan perpanjangan tangan kelompok kepentingan yang disinyalir dapat menghambat keberlanjutan pembangunan (Sutisna 2016). Bahkan Jawara dalam proses tindakan komunikatif diam-diam melakukan manipulasi pesan untuk kepentingannya.

Yang menarik adalah ketika ditemukan gap temuan yang terjadi dalam fenomena elite lokal dalam pembangunan serta esklasi politik lokal. Elite lokal disisi lainnya dalam perspektif tindakan komunikatif berupaya mendorong pemikiran kritis masyarakat terhadap fenomena politik lokal. Masyarakat secara rasional diajak berpikir tentang idealisme politik dan dampaknya bagi pembangunan (Rusadi 2014). Dalam perspektif ini yang dikembangkan adalah terciptanya ruang publik sehingga masyarakat dapat mendialogkan segala permasalahan yang ada. Lebih luas lagi, elite lokal menjadi inisiator dan mediator dalam terwujudnya civil society (Sujatmiko \& Iwan Gardono 2006).

Gap lainnya dari kasus Jawara di Pandeglang sebagai elite lokal terletak pada pola pendekatan komunikasi yang berbeda dan khas disetiap interaksi. Banyak Jawara yang masih mempertahankan peran tradisionalnya berupaya membangun kesadaran kritis masyarakat. Pesanpesan komunikasi yang dibangun mengandung unsur komfrehensibilitas sehingga konsensus yang dicapai berdampak pada upaya-upaya peningkatan partisipasi masyarakat dalam pembangunan. 
e-ISSN: 2686-0724 - p-ISSN: 0853-4470 - Vol. 02, No. 02 (2019), pp. 104-116 Jawara pada titik ini berupaya agar bagaimana interaksi politik yang dilakukan efektif dan berdampak pada keberdayaan masyarakat dan semaksimal mungkin Jawara kemudian berupaya membangun kepercayaan dan menghindari gap-gap komunikasi.

Dualism interaksi politik Jawara semacam ini dapat dijawab oleh teori tindakan komunikatif yang mengedepankan unsur rasionalitas dan kesetaraan peran. Lebih kanjut, persoalan interaksi politik Jawara dalam membangun konsesnsus dengan masyarakat, komunikasi yang digunakan menggunakan konsep low context dengan pendekatan patron klien dimana masyarakat lebih mengedapankan hubungan clientist dibandingkan hubungan rasional (Karomani 2008).

Low Context diinterpretasikan dengan kata yang menampilkan makna tersurat, tidak bermakna ganda sehingga tidak perlu banyak upaya untuk mengartikannya, tidak mengandung candaan dan langsung menjelaskan maksud atau arti sebenarnya. Istilah "patron' berasal dari ungkapan bahasa Spanyol yang secara etimologis berarti seseorang yang memiliki kekuasaan (power), status, wewenang dan pengaruh. Sedangkan klien berarti "bawahan" atau orang yang di perintah dan yang di suruh. Pola hubungan patron klien merupakan aliansi dari dua kelompok komunitas atau individu yang tidak sederajat. Baik dari segi status, kekuasaan, maupun penghasilan sehingga menempatkan klien dalam kedudukan yang lebih rendah (inferior) dan patron dalam kedudukan yang lebih tinggi (superior). Patron adalah orang yang berada dalam posisi untuk membantu klien-kliennya (Scott, 1983).

Berbeda halnya, ketika Jawara berkomunikasi dengan partai politik, tokoh masyarakat, tokoh pemuda dan lainnya maka konsep komunikasi yang digunakan cenderung high context dengan pendekatan teori tindakan komunikatif. High Context membutuhkan informasi-informasi tambahan untuk memahami arti dari isi atau pesan komunikasinya. Pada High Context sifatnya terkadang tidak to the point alias tersirat. High Context adalah perkataan atau pernyataan yang sekedar basa basi atau kata yang sekedar candaan yang tidak memberi arti yang serius, maksudnya adalah tipe high contect ini merupakan tipe yang suka berputar-putar dalam memberikan pernyataan sebelum menjelaskan maksud atau arti yang sebenarnya.

Dengan demikian, sebenarnya interaksi politik Jawara dengan masyarakat bukanlah sesuatu yang patut diistimewakan dalam proses politik dan bukan pula sebagai proses yang patut dicurigai, tetapi lebih sebagai proses yang alami dalam suatu kekuasaan atau pemerintahan (Timmer 2007). Persoalan menjadi menarik karena kesahihan dan validitas pesan dalam interaksi politik Jawara memberikan corak dan dampak tersendiri pada pembangunan daerah. Di daerah-daerah yang cenderung demokratis, kesahihan dan validitas politik mengarah pada proses penguatan rakyat. Lain halnya dengan daerah-daerah yang cenderung menerapkan pendekatan teknokrasi, paternalistik dan clientism seperti terjadi di Pandeglang. Kesahihan dan validitas pesan sulit terwujud dalam pembicaraan, argumen politis yang disampaikan cenderung dipenuhi oleh praktik-praktik marginalisasi peran sehingga masyarakat dikondisikan agar tidak kritis.

Untuk memfokuskan proses penelitia, peneliti merumuskan dua asumsi agar kerangka kajian penelitian tetap berada dalam lingkaran teori tindakan komunikatif. Asumsi Pertama, akar persoalan clientism, patron klien dan patrimonial (lokalitas) yang mengakar di tengah-tengah masyarakat Pandeglang menjadi penghambat utama terbentuknya tindakan komunikatif. Diskursus praktis proseduralis yang berciri inklusif, otonom, egaliter dan tanpa paksaan menjadi sulit terbentuk. Jawara disatu sisi ingin mendorong partisipasi masyarakat dalam pembangunan tetapi disisi lainnya diam-diam melakukan manuver politik agar masyarakat tidak memiliki daya kritis.

Asumsi kedua adalah dinamika politik lokal yang cenderung berorientasi pada budaya clientism, patrimonial dan politik dinasti membatasi ruang gerak Jawara dalam melakukan upayaupaya penyadaran kritis. Selain banyak Jawara yang melakukan manipulasi pesan karena kepentingan pragmatis, Jawara sebagai elite lokal tidak memiliki kesetaraan untuk secara otonom membangun konsensus, sehingga kemudian persoalan pembangunan di Pandeglang menjadi sulit terpecahkan dan masyarakat Pandeglang belum secara optimal dapat berpartisipasi dalam pembangunan. 
e-ISSN: 2686-0724 - p-ISSN: 0853-4470 - Vol. 02, No. 02 (2019), pp. 104-116

Berdasarkan permasalahan dan dua asumsi diatas, maka tujuan penelitian ini adalah (1) mengkonstruksikan interaksi politik Jawara dalam pembangunan (2) mendekatkan persoalan interaksi politik Jawara dengan perspektif teori tindakan komunikatif.

\section{KERANGKA TEORI}

Teori yang dipergunakan pada penelitian ini adalah teori tindakan komunikatif yang dipelopori oleh Jurgen Habermas, merupakan tokoh filsafat kritis. Ciri khas dari filsafat kritisnya berkaitan dengan kritik terhadap hubungan-hubungan sosial. Pemikiran Habermas merefleksikan masyarakat serta diri dalam konteks dialektika struktur-struktur sosial dan emansipasi. Menurut Habermas (1984), secara konseptual ada empat model tindakan dalam teori kritis yakni: (1) tindakan teologis, (2) tindakan yang diatur secara normative, (3) tindakan dramaturgis, (4) tindakan komunikatif.

Tindakan teologis mengoreintasikan diri dan pada tujuan dari setiap keputusan dengan memanfaatkan sarana secara tepat. Tindakan ini bergerak dengan model bawah (subjek atau aktor) menuju ke atas (kesepakatan yang akan dijalin bersama) yang kemudian diperluas menjadi model tindakan strategis dengan argumen bahwa proses pemanfaatan sarana dan langkah-langkah yang tepat tersebut diambil untuk mencapai tujuan bersama. Tindakan ini juga diposisikan sebagai pembuka aspek rasionalitas tindakan, yakni tindakan rasionalitas-bertujuan.

Tindakan normative, bergerak dengan model dari atas ke bawah dengan aktor diharapkan berperilaku sesuai dengan norma yang telah disepakati dan mengorientasikan tindakannya kepada nilai-nilai bersama (Habermas, 1984). Konteks normatif menjadi dasar interaksi dalam totalitas relasi antarpribadi, artinya aktor selain berelasi terhadap keadaan situasinya secara bersamaan juga berelasi dengan dunia sosial yang menjadi bagian dari aktor sebagai subjek yang memiliki peran tertentu.

Tindakan dramaturgis, aktor mengungkapkan citra tertentu untuk membangun kesan tentang dirinya sendiri dengan mengungkapkan sisi subjektivitasnya (Habermas, 1984). Model dalam tindakan ini digunakan dalam deksripsi interaksi yang diorientasikan secara fenomenologis. Dalam tindakan dramaturgi, tindakan sosial diartikan sebagai perjumpaan partisipan dalam membentuk sesuatu yang bersifat publik yang dapat diperlihatkan dan saling ditampilkan. Suatu pertunjukan memungkinkan aktor menampilkan sisi subjektivitasnya yang ingin diperhatikan publik dengan cara tertentu.

Tindakan komunikatif mengarah pada interaksi dua orang subjek atau lebih dalam berbicara, bertindak dengan tujuan membangun hubungan antar personal (Habermas, 1984). Subjek berusaha mencapai dan mengkoordinasikan pemahaman mengenai situasi dan rencana tindakan melalui kesepakatan. Masing-masing subjek kemudian melakukan interpretasi definisi-situasi demi terwujudnya konsensus. Untuk keperluan ini, Habermas menitikberatkan bahasa (media linguistik) dalam tindakan komunikatif.

Habermas (1987) juga menekankan rasionalitas hanya ada dalam model tindakan komunikatif, karena tiga alasan: Pertama, dalam tindakan teologis, bahasa digunakan hanya sebagai media pembicara yang ingin mencapai keberhasilannya sendiri. Kedua, dalam hal tindakan normatif, bahasa digunakan sebagai media yang mentransmisikan nilai-nilai budaya dan membawanya ke suatu konsensus. Ketiga, dalam hal tindakan dramaturgis bahasa digunakan sebagai media presentasi diri. Bahasa diasimilasikan ke dalam bentuk ekspresi stilistik, yaitu penggunaan bahasa dan gaya bahasa dan estetis. Sedangkan tindakan komunikatif lebih mengutamakan bahasa sebagai media komunikasi bebas tekanan, di mana pembicara dan pendengar dalam berelasi dan berkomunikasi secara simultan merujuk pada hal-hal yang ada di dunia objektif yang sedang terjadi.

Pada pembahasan model tindakan komunikatif, ada enam hal yang diajukan oleh Habermas untuk memahaminya, namun peneliti hanya mengambil tiga hal yang cukup mencakup keenam hal tersebut yang memiliki kesesuaian dengan kerangka penelitian, yaitu (1) masalah koordinasi tindakan, (2) perbedaan ilokusioner dan proluksioner yang mempunyai orientasi kepada keberhasilan dan orientasi kepada tercapainya pemahaman, dan (3) peran klaim validitas. 
e-ISSN: 2686-0724 - p-ISSN: 0853-4470 - Vol. 02, No. 02 (2019), pp. 104-116

Pertama, koordinasi tindakan. Sebelum terjadinya tindakan komunikatif, setiap orang membekali dirinya sendiri dengan pola tindakan sendiri-sendiri, tercapainya pemahaman dalam bahasa direpresentasikan pada model subjek yang bertindak secara teologis, timbal balik dan saling mempengaruhi. Koordinasi tindakan yang hanya terbentuk melalui kepentingan yang saling melengkapi dapat secara normatif ditata ulang dengan cara melakukan validitas yang didasarkan pada kesepakatan (Habermas, 1984).

Kedua, perbedaan iluksioner dan proluksioner yang mempunyai orientasi kepada keberhasilan dan orientasi kepada tercapainya pemahaman. Dalam hal ini, tindakan sosial dapat dipilah-pilah menurut apakah para partisipan menerapkan sikap orientasi pada keberhasilan atau orientasi pada pencapaian pemahaman sehingga dapat dipahami unsur-unsur struktural proses pencapaian pemahaman. Pengamatan dapat dilihat melalui seorang subjek memberikan sesuatu untuk dipahami kepada subjek lainnya dan secara tidak langsung menyuruhnya membentuk opini tertentu atau menjalankan kehendak tertentu. Hal ini kemudian menimbulkan kesan bahwa seorang subjek secara terang-terangan memanfaatkan orang lain untuk mencapai tujuannya sendiri.

Ketiga, peran klaim validitas. Ada tiga macam klaim dalam tindakan komunikatif: (1) jika subjek melakukan kesepakatan tentang dunia alamiah dan objektif, berarti mencapai klaim kebenaran (truth), (2) jika subjek melakukan kesepakatan tantang pelaksanaan norma-norma dalam dunia sosial berarti mencapai klaim ketepatan, (3) jika ada kesepekatan tentang kesesuaian antara dunia batiniah dan ekspresi seseorang berarti mencapai klaim autentisitas atau kejujuran (sincerety). Selanjutnya, jika kita mencapai kesepakatan atas klaim-klaim diatas secara keseluruhan berarti mencapai klaim komprehensibilitas dan setiap komunikasi yang efektif harus mencapai klaim keempat ini (Habermas 1984).

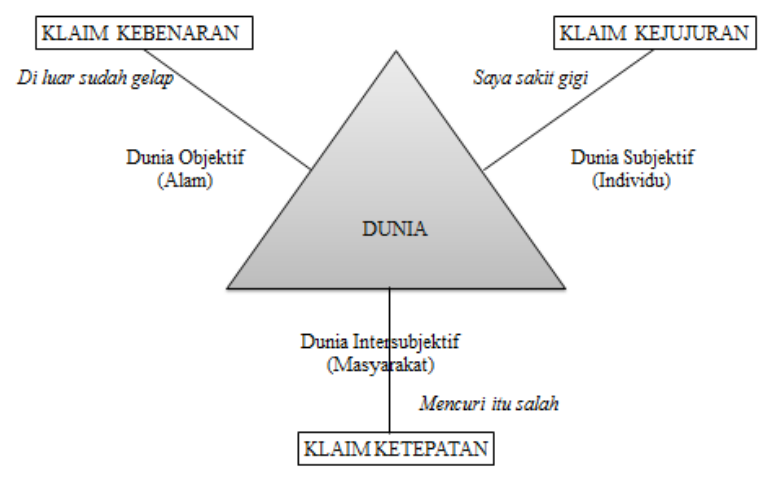

Gambar 1. Klaim-Klaim Habermas

Sumber Habermas 1984

Lebih lanjut, Habermas menganalogikan rasionalitas sebagai tindakan komunikatif yang diorientasikan untuk mencapai kesepakatan bersama atau konsensus. Untuk mencapai kesepakatan, subjek harus memiliki apa yang disebut sebagai kompetensi komunikasi yang terhubung dengan kemampuan dalam berbahasa. Dijelaskan bahwa tindakan komunikatif dalam mewujudkan keshahihan tidak hanya dapat diidentikan dengan kompetensi komunikasi saja, karena memang melibatkan moment kognitif, interaktif, dan ekspresif (Habermas, 1984).

Implikasinya, tindakan komunikatif yang dibangun dengan relasi dan kuasanya, secara kognitif, interaktif dan ekspresif harus mencerminkan klaim-klaim kesahihan. Klaim-klaim ini yang kemudian menghadirkan pemikiran dan argumentasi kritis yang direfresentasikan melalui dialog dalam ruamg publik. Dialog-dialog ini kemudian membangun kesadaran dan partisipasi (deliberatif). Di sisi lainnya, Habermas memperkuat pandangannya bahwa tindakan komunikatif tidak bisa hanya difokuskan kepada penerpaan norma tradisonal, karena historisme telah meruntuhkan kesahihan alamaiah-tradisonal dari sistem nilai yang berorintasi pada tindakan. 
Asumsi yang diangun Habermas adalah bahwa masyarakat itu pada hakekatnya bersifat komunikatif, mengutamakan peranan struktur-struktur sosial dalam melakukan perubahan sosial. Teori tindakan komunikatif Habermas menggambarkan tindakan komunikasi yang mengarahkan pada konsensus dengan berbagai kepentingan dapat digeneraliasasikan berdasarkan pada kepentingan umum. Habermas memahami bahwa rasionalitas berhubungan dengan tiga macam rasionalitas yang otonom, yaitu rasionalitas kognitif-instrumental (sesuai dengan rasionalitas-tujuan dalam pengertian Weber), rasionalitas praktis-moral, dan rasionalitas praktis-estetis. Jika kompleksitas hidup dirasionalisasikan, maka menghasilkan pengetahuan yang memiliki klaim kesahihan (validity claim) tertentu hingga dalam kompleksitas ini subyek dapat mencapai konsensus.

\section{METODE PENELITIAN}

Metode yang digunakan dalam penelitian ini menggunakan pendekatan kualitatif. Denzim \& Lincoln (2009) menyatakan penelitian kualitatif merupakan metodelogi dan praktik penelitian, yang memiliki makna yang berbeda pada tiap tahap perkembangannya. Peneliti memilih pendekatan kualitatif dengan argumen bahwa kualitatif merupakan metode yang memiliki ragam fokus (multimethod in focus), meliputi pendekatan naturalistik interpretatif terhadap interaksi politik Jawara sebagai subjek.

Merujuk pada hal ini, peneliti kemudian mempelajari sesuatu dalam setting social dan setting politik interaksi politik Jawara, dengan cara mencoba membangun pemahaman atau interpretasi terhadap makna yang dimaksud oleh Jawara serta masyarakat terkait pembangunan yang diungkapkan di hadapan peneliti. Peneliti menggunakan paradigma konstruktivis yang didasarkan pada asumsi bahwa interaksi politik Jawara merupakan isu empiris yang fenomenal di Banten dan merupakan realitas lokal yang dikonstruksi secara spesifik. Mengutip Barger dan Luckam (1996), perspektif konstruktivis menganggap interaksi politik Jawara terpotret dalam beragam bentuk konstruksi mental, berdasar pada situasi sosial dan pengalamannya, bersifat lokal dan spesifik.

Konstruktivis melihat bahwa setiap pernyataan, pesan, simbol yang digunakan Jawara adalah tindakan-tindakan penciptaan makna untuk mencapai konsensus. Subjek melakukan kontrol terhadap-maksud-maksud tertentu (Ardianto \& Anees 2007). Inti konstruktivis adalah memberi kepercayaan kepada peneliti bahwa setiap dari kita mengkonstruksi dunia secara sosial melalui interaksi komunikatif untuk mencapai pemahaman timbal balik.

Penelitian dilakukan di Kabupaten Pandeglang selama enam bulan, dari bulan Juli sampai Desember 2018. Adapun teknik pengambilan informan dilakukan secara purposif melalui teknik key informan yaitu para informan dengan karakter spesifik yang dianggap menguasai dan terkait dengan permasalahan. Informan penelitian yang diambil, mewakili tokoh Jawara, birokrat, tokoh masyarakat, dan masyarakat biasa yang terlibat dalam persoalan pembangunan.

Penilitian dan pengamatan dilakukan pada level makro dan mikro. Makro dimaksudkan pada informan yang memiliki akses dan berinteraksi pada level Kabupaten dan Provinsi sedangkan mikro adalah informan yang berinteraksi di area Kecamatan dan Desa. Untuk pengamatan, difokuskan pada interaksi politik yang dilakukan informan baik dalam komunikasi formal maupun komunikasi informal. Interaksi politik Jawara diamati baik dalam aktvitas politik formal maupun aktivitas politik informal Jawara dalam pembangunan, meliputi interaksi politik dalam organisasi formal, interaksi politik dengan partai politik dan interaksi politik dengan pemerintah.

Pengambilan data primer dilakukan melalui teknik wawancara mendalam (in depth interview) dan pengamatan terlibat (participatory observation). Sementara, data sekunder diperoleh melalui teknik studi literatur sebagai data pelengkap dalam mengkomfirmasi data primer. Teknik analisis data menggunakan tahapan: (1) membaca secara cermat keseluruhan catatan penting (2) memberikan kode pada topik-topik penting (3) menyusun tipologi (4) membaca pustaka yang terkait karakteristik komunikasi Jawara. Berdasarkan seluruh analisis, peneliti kemudian melakukan rekonstruksi dalam bentuk deskripsi, narasi dan argumentasi. 
e-ISSN: 2686-0724 - p-ISSN: 0853-4470 - Vol. 02, No. 02 (2019), pp. 104-116

Penelitian ini merupakan bagian mikro dari penelitian makro yang sedang peneliti lakukan terkait aktivitas politik Jawara dalam pembangunan sehingga penelitian ini memiliki beberapa aspek kebaharuan. Dari aspek teori tindakan komunikatif, penelitian ini mencoba menampilkan gap komunikasi dari model-model teori tindakan komunikatif, sedangkan dari sisi praksis mencoba mengungkap motif dan persoalan tersembunyi Jawara dalam melakukan interaksi politik. Pertemuan model-model tindakan komunikatif dalam penelitian ini, menjadi keunikan tersendiri sehingga penelitian ini dapat dikategorikan sebagai kajian yang menganalisis teori. Secara metodelogis, penelitian ini juga akan menghasilkan pengkategorian objek penelitian yang beragam yang merupakan produk interaksi peneliti dengan tineliti.

\section{HASIL PENELITIAN}

Bila melihat laju pembangunan di Kabupaten Pandeglang dan tingkat kemiskinan yang ada, akan terlihat krusialnya peran Jawara dalam menentukan laju pembangunan dan partisipasi masyarakat. Kuatnya peran Jawara sebagai kekuatan elite culture dalam pembangunan (melalui praktik komunikasi politik) menghasilkan relasi patron klien yang kemudian berdampak pada hubungan khusus yang disebut clientism dalam praktik pembangunan.

Clientism yang dimaksud adalah satu bentuk hubungan sosial dengan patron sebagai pihak yang berkuasa atau kaya, memberikan pekerjaan, perlindungan, infrastruktur dan manfaat lainnya kepada client yang tidak berdaya (miskin) sehingga menimbulkan dampak imbalan dari client dalam bentuk kesetiaan, pelayanan dan dukungan politik kepada patron (hubungan superiorinferior). Realitas empirik inilah yang terjadi dalam sistem kekuasaan dan pembangunan di Banten dalam sebutan sistem patriomonial.

Osborne dan Gaebler (2013) menjelaskan bahwa saat memasuki paradigma pembangunan "reinventing government melalui prinsip "community owned government: empowering more than serving menegaskan pentingnya partisipasi masyarakat sebagai indikator utama keberhasilan pembangunan. Hal ini juga mempertegas bahwa masyarakat tidak lagi diperlakukan sebagai objek pembangunan tetapi lebih sebagai subjek yang aktif dan pemilik pembangunan itu sendiri (owner of government) serta mampu bertindak secara bersama-sama untuk mencapai tujuan yang lebih baik (solidarity). Budiyanti (2018) menitikberatkan bahwa kepentingan masyarakat tidak lagi dipandang sebagai agresi kepentingan pribadi melainkan sebagai dialog (tindakan komunikatif) serta partisipasi masyarakat dalam pembangunan.

Asumsinya, tindakan komunikatif dapat meningkatkan kemandirian masyarakat. Sahab (2012) menjelaskan bahwa dalam tindakan komunikatif mendorong individu-individu privat terlibat dalam perdebatan rasional kritis dalam dialog, untuk membangun apa yang disebut Immanual Kant dengan "kesepakatan publik" atau "opini publik" atau Habermas menyebutnya sebagai "konsensus yang berdasar pada klaim keabsahan", yang kemudian mengemuka sebagai universalitas empirik dan sebagai landasan opini mayoritas".

Dalam realitas empiris di lapangan, tindakan komunikatif dalam wahana-wahana ruang publik pada masyarakat Pandeglang bercirikan inklusif, otonom, egaliter dan tanpa paksaan terpotret dalam interaksi politik Jawara baik dengan masyarakat-pemerintah-partai politik. Interaksi politik Jawara memunculkan opini mayoritas sebagai akibat dari intensitas komunikasi dalam membangun konsensus. Jawara dengan kemampuan serta kompetensi komunikasi yang dimilikinya secara proaktif membangun opini mayoritas terkait persoalan pembangunan yang merupakan implikasi dari ruang-ruang publik yang hanya mampu dimanfaatkan oleh sebagian masyarakat dan itupun didominasi oleh Jawara. Sayangnya interaksi politik Jawara kemudian terjebak pada persoalan clientelism, corporation sehingga ada indikasi Jawara cenderung berpihak pada kepentingan kelompoknya.

Selain sifat pembangunan partsipatori (deliberative) yang mensyaratkan keterlibatan semua masyarakat dalam pembangunan masih menjadi bagian yang parsial di Pandeglang. Hal ini juga dikarenakan masyarakat cenderung mewakilkan asprasi politiknya kepada Jawara. Tetapi kemudian Jawara menjadi kurang aspiratif dan cenderung lebih mengutamakan kepentingan diri dan 
e-ISSN: 2686-0724 - p-ISSN: 0853-4470 - Vol. 02, No. 02 (2019), pp. 104-116 kelompoknya, karenanya tindakan komunikatif pada masyarakat Pandeglang menjadi sebuah utopia. Inilah yang dikatakan Habermas sebagai imperative categoris: dimana ada tendensi kekuasaan pada opini mayoritas dari elite kekuasaan atas klaim kebenaran hakiki.

Pola patronase yang dibangun Jawara menjadikan sifat otonom masyarakat, egaliter dan tanpa paksaan menjadi hilang, karena tingkat kepercayaan masyarakat yang begitu tinggi terhadap Jawara. Sistem patrimonial menjadikan sifat inklusif, egaliter dan tanpa paksaan sulit terbentuk karena hanya elite kekuasaan saja yang menduduki posisi krusial dalam pembangunan. Kondisi ini terus menerus diwariskan, diperlihara dalam struktur kekuasaan yang lambat laun membudaya ditengah-tengah masyarakat.

Implikasi lebih lanjut, sistem dan patriomonial yang begitu kuat di Pandeglang secara diamdiam mempermudah Jawara dalam membangun kesahihan-kesahihan politik yang dibutuhkan dalam membangun konsensus. Misalnya Jawara sebagai aktor politik sangat leluasa membangun opini dengan menggunakan jargon "pembangunan untuk rakyat" atau "kesejahteraan untuk masyarakat"dan atau jargon lainnya dengan bermodalkan patron client dan budaya patriomonial. Masyarakat dengan sukarela mengikuti apa yang dituturkan Jawara dan tanpa perlu mengkritisinya, dan tanpa perlu melakukan dialog-dialog.

Persoalan inilah yang kemudian membelenggu masyarakat di Pandeglang, sehingga tindakan komunikatif masyarakat yang sedianya dapat disalurkan melalui dialog-dialog kritis, kesadaran kritis menjadi sulit terwujud. Implikasi yang lebih jauh adalah masyarakat tidak memiliki kesadaran kritis, partisipasinya tidak mengarah pada upaya-upaya pembebasan diri yang mendorong agar pembangunan menjadi partisipatif. Terjadi benturan wacana dalam ruang publik yang tidak berfungsi, dialog-dialog dipenuhi dengan kepentingan, sehingga kemudian konsensus yang dibangun adalah konsesnsus untuk kepentingan sepihak dan tidak memenuhi unsur legitimasi.

Perihal lain yang tak kalah krusialnya dalam interaksi politik Jawara dalam pembangunan adalah realitas empiris yang menunjukan adanya gap praksis dan gap politis. Jawara terbagi menjadi dua sisi yang berlawanan, ada sebagaian Jawara yang pro terhadap pembangunan (status quo) dan ada yang kontra terhadap pembangunan (membangun kesadaran kritis). Ada juga Jawara yang terkooptasi secara politik pragmatis ada juga Jawara yang masih memerankan peran tradisionalnya dan tidak terpengaruh dengan arus kapitalisme politik. Kedua gap ini kemudian menjadi fakta empirik dalam persoalan interaksi politik Jawara dalam membangun kesahihan dan kosensus. Jawara dalam interaksi politik tidak sedikit secara politis dan secara moril berbenturan di lapangan karena persoalan idealisme dan kepentingan dalam membangun konsesnsus.

Mengaitkan persoalan empiris pembangunan di Pandeglang dengan perspektif tindakan komunikatif yang ditawarkan Habermas pada interaksi politik Jawara yang kental dengan sistem patrimonialnya, maka peneliti mengkonstruksikan interaksi politik Jawara seperti pada Gambar 2.

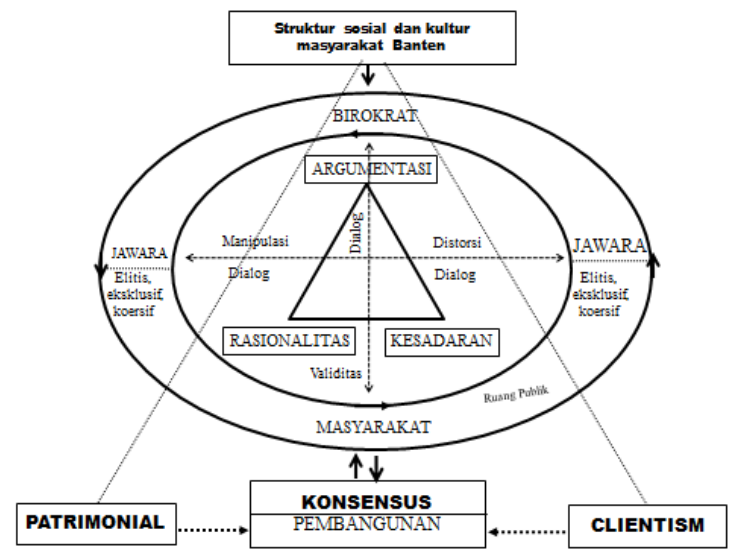

Dalam Gambar 2, peneliti mencoba membentangkan beberapa unsur dan faktor yang ada dan saling berinteraksi, terhubung terkait dalam interaksi politik Jawara pada pembangunan. Struktur sosial masyarakat Pandeglang merefresentasikan budaya patriomonilisme dan clientism 
e-ISSN: 2686-0724 - p-ISSN: 0853-4470 - Vol. 02, No. 02 (2019), pp. 104-116 yang mengakar dalam ruang-ruang politik dan pembangunan sehingga pembangunan di daerah Pandeglang menjadi timpang, tidak merata dan cenderung memarjinalkan masyarakat. Jawara sebagai elite lokal dalam interaksi politiknya kemudian menghasilkan dua orientasi komunikasi Jawara: validitas pesan dan manipulasi pesan.

Beberapa asumsi dalam penelitian ini mengacu asumsi-asumsi yang dibangun sebelumnya. Kesadaran kritis masyarakat sebagai buah hasil dari aktivitas-aktivitas membangun validitas pesan idealnya mengarah pada bagaimana konsep-konsep pembangunan yang mestinya dipahami sebagai upaya menumbuhkan kesadaran kritis amsyarakat dalam pembangunan. Sedangkan marjinalisasi masyarakat dalam pembangunan merupakan dampak dari kegagalan interaksi politik Jawara yang berakibat pada distorsi komunikasi.

Tindakan komunikatif yang nampak dalam interaksi politik Jawara sebagai dampak dari politik, juga menggambarkan keterhubungan-keterhubungan bagaimana interaksi politik Jawara memiliki hubungan yang sangat equivalen dengan pembangunan daerah dan situasi sosial politik masyarakat Pandeglang. Komunikasi politik Jawara misalnya, memiliki keterhubungan kuat dengan dialog, ruang publik dan marjinalisasi, Jawara memiliki kekuatan dan kemampuan ekonomi, politik dan sosial yang idealnya diperuntukkan untuk membangun validitas pesan bukan sebaliknya memanipulasi pesan. Benturan ini sangat nyata terlihat ketika ada dua kelompok Jawara yang disatu sisi melakukan penyadaran kritis tetapi di sisi lainnya melakukan rangkaian manpulasi pesan. Bagi masyarakat pesan-pesan yang berbenturan ini menimbulkan distorsi pesan yang kemudian masyarakat sulit mencapai konsensus.

Kondisi yang terjadi dalam interaksi politik Jawara (dengan budaya patrimonialnya) sulit sekali menciptakan suasana demokratis. Kekuatan Jawara sebagai informal leader dan elite lokal di tengah-tengah masyarakat jauh lebih mengakar dibandingkan dengan kekuatan otoritas legal formal sekalipun, sehingga kekuatan struktur kekuasaan formal pun bergeser kepada nilai-nilai kultural melalui subkultur Jawara. Seperti disampaikan sebelumnya, bahwa interaksi politik Jawara bukanlah sesuatu yang istimewa dan atau aneh, tetapi merupakan suatu yang alamiah yang tumbuh ditengah-tengah masyarakat. Tetapi persoalannya terletak pada kultur sosiologis masyarakat Pandeglang dalam pembangunannya cenderung menerapkan pendekatan teknokratis, paternalistik dan clientism sehingga kesahihan dan validitas pesan sulit terwujud dalam interaksi politik Jawara. Dialog-dialog yang dibangun Jawara cenderung dipenuhi oleh praktik-praktik marginalisasi sehingga masyarakat dikondisikan agar tidak kritis.

Pendekatan teknokratis dan pendekatan paternalistik dalam pembangunan di Kabupaten Pandeglang memposisikan masyarakat sebagai objek-sasaran pembangunan dan tidak memberikan kesempatan kepada masyarakat untuk mempertanyakan, mengklarifikasi ataupun mengkritik pembangunan. Sedangkan pendekatan paternalistik sangat kentara ketika pemerintah Kabupaten Pandeglang memposisikan dirinya sebagai seorang ayah yang melakukan tindakan protektif terhadap "anaknya" masyarakat, dan memperlakukan masyarakat sebagai anak kecil yang tidak perlu mengetahui banyak hal tentang penyelenggaraan program dan memposisikan masyarakat untuk menerima saja segala bentuk keputusan.

Dalam beberapa kasus, pembicaraan dan argumentasi yang disampaikan dalam interaksi politik Jawara telah mengubah: Pertama, orientasi-orientasi masyarakat menjadi $a$ politis. Kedua intervensi Jawara yang makin kuat melemahkan tatanan sosial kultural dan memarginalkan masyarakat dalam pembangunan. Ketiga, Jawara sebagai elite lokal dalam praktiknya terkooptasi oleh kepentingan pragmatis atas nama pembangunan. Berdasarkan pada persoalan-persoalan ini maka hegemoni pembangunan dan marginalisasi masyarakat di Pandeglang dapat diasumsikan bukan karena kondisi tetapi lebih pada konsekuensi. Sebagai suatu konsekuensi maka hal ini merupakan efek dari relasi-relasi sosial Jawara-pemerintah-partai politik-masyarakat yang terbatas dan timpang.

Temuan-temuan di atas secara tidak langsung mencoba mengantarkan fenomena bahwa keberadaan Jawara memperkuat keberadaan kelompok-kelompok kepentingan dan mengabaikan kepentingan masyarakat. Lebih menarik ketika ditemukan gap temuan yang terjadi dalam fenomena elite lokal serta esklasi politik lokal. Elite lokal disisi lainnya dalam perspektif tindakan 
komunikatif berupaya mendorong pemikiran kritis masyarakat terhadap fenomena politik lokal. Sujatmiko, Iwan Gardono (2006) yang dikembangkan kemudian adalah ruang publik dimana masyarakat dapat mendialogkan segala permasalahan yang ada. Lebih luas lagi, elite lokal menjadi inisiator dan mediator dalam terwujudnya civil society.

Gap lainnya dari kasus Jawara di Pandeglang sebagai elite lokal terletak pada pola pendekatan komunikasi yang berbeda dan khas disetiap interaksi. Banyak Jawara yang masih mempertahankan peran tradisionalnya berupaya membangun kesadaran kritis masyarakat. Pesanpesan komunikasi yang dibangun mengandung unsur komfrehensibilitas sehingga konsesnsus yang dicapai berdampak pada upaya-upaya peningkatan kesejahteraan hidup masyarakat itu sendiri. Jawara pada titik ini berupaya agar bagaimana komunikasi-komunikasi politik yang dilakukan efektif dan berdampak pada keberdayaan masyarakat itu sendiri. Semaksimal mungkin Jawara kemudian berupaya membangun kepercayaan dan menghindari gap-gap komunikasi.

Bila dilihat dari realitas empiris di lapangan, persoalan interaksi politik Jawara ini berawal dari sistem sosial, politik dan budaya di Pandeglang yang memberikan ruang tumbuh suburnya informal leader dan elite culture yang pengaruhnya terkadang melebihi kuasa dan otoritas formal leader dalam membangun konsesnsus. Untuk kasus Pandeglang peran informal leader ini telah secara apik diperankan Jawara yang kemudian mendominasi perpolitikan lokal. Model politik lokal, demokrasi dan relasi kekuasaan di Pandeglang yang memberikan kuasa lebih kepada Jawara ternyata membuat Pandeglang tidak semakin maju, pembangunan semakin menunjukkan kemunduran, kemiskinan makin meningkat (BPS Pandeglang 2018) sehingga keberadaan Jawara sebagai informal leader dalam beberapa praktik sosial memicu marginalisasi sosial.

Penelitian dengan fokus pada interaksi politik Jawara berhasil membentangkan persoalan dan mengungkapkan bagaimana interaksi politik Jawara dalam membangun konsensus dan mencari legitimasi politik. Komunikasi politik Jawara berusaha membangun pemahaman dan kesahihan pesan sebagai modal kekuatan sosial dan budaya dan agar kensensus dapat terus terwujud. Pembangunan dianggap sebagai arena interaksi masyarakat yang menghasilkan makna, kesepahaman dan kesepakatan yang memiliki makna tertentu yang kemudian diolah menjadi sebuah legitimasi politis. Pada pertautan dan bentang-bentang persoalan interaksi politik Jawara inilah kemudian memunculkan temuan-temuan bahwa interaksi politik Jawara telah gagal mengantarkan Pandeglang dalam pembangunan yang demokratis.

Terkait dengan model-model tindakan komunikatif Jawara dalam berinteraksi politik lebih dominan mengacu pada model tindakan normatif dan tindakan dramaturgis. Tindakaan normatif Jawara bergerak dengan model dari atas ke bawah. Implikasinya adalah Jawara lebih dominan membuat agenda-agenda politik yang direfresentasikan melalui aktivitas dan ruang-ruang keseharian masyarakat.posisi masyarakat dalam tindakan normatif selalu merasa tertekan jika tidak mengikuti opini mayoritas karena secara koersif Jawara melakukan intimidasi sosial yang membuat masyarakat menjadi tidak nyaman. Masyarakat pada akhirnya berperilaku sesuai dengan norma yang telah disepakati dan mengorientasikan tindakannya kepada nilai-nilai bersama. Konteks normatif ini kemudian menjadi dasar interaksi-interaksi politik Jawara dalam totalitas relasi dengan amsyarakat, artinya Jawara selain berelasi terhadap keadaan situasinya secara bersamaan juga berelasi dengan dunia sosial yang menjadi bagian dari aktor sebagai subjek yang memiliki peran tertentu.

Dalam tindakan dramaturgis Jawara secara intensif mengungkapkan citra tertentu untuk membangun kesan tentang dirinya sendiri dengan mengungkapkan sisi subjektivitasnya. Jawara sebelumnya merancang deksripsi interaksi politiknya yang diorientasikan secara fenomenologis seolah-olah ini merupakan realitas alami dari amsyarakat itu sendri. Dalam tindakan dramturgis, interaksi politik Jawara diartikan sebagai perjumpaan Jawara dengan masyarakat dalam pembanunan untuk membentuk sesuatu yang bersifat publik yang dapat diperlihatkan dan saling ditampilkan. Model dramaturgi memungkinkan Jawara menampilkan sisi subjektivitasnya yang ingin diperhatikan kepada masyarakat dengan cara tertentu. Dalam model inilah kecendrungan manipulasi dan distorsi pesan dilakukan Jawara untuk kepentingan citra politiknya. 


\section{KESIMPULAN}

Berdasarkan asumsi-asumsi di atas, maka kesimpulan dalam penelitian ini adalah (1) konstruksi dari interaksi politik Jawara dalam pembangunan belum memberikan manfaat sepenuhnya terhadap kesejahteraan masyarakat Banten karena interaksi politik Jawara terjebak pada persoalan pragmatism, clientism, patrimonial dan persoalan korporasi, (2) teori tindakan komunikatif dalam penelitian ini tidak bisa secara an sich melihat pembangunan dalam konteks tujuan dari tindakan komunikatif itu sendiri tetapi perlu juga disandingkan dengan realitas struktur dan kultur masyarakat. Pada posisi inilah konsep-konsep komunikasi pembangunan lebih mudah dilihat. Interaksi politik Jawara dalam pembangunan disatu sisi berbicara tentang rasionalitas dan objektifitas dalam berfikir, bertindak, mengolah dan menyusun pesan tetapi disisi lain muncul unsur dominasi dan hegemoni dalam konteks politik lokal.

\section{DAFTAR PUSTAKA}

Abdur, Rozaki. 2009. Social origin dan politik kuasa blater di Madura. Journal Kyoto review of Southeast Asia. (11).

Antonius, Galih Prasetyo. 2012. Menuju demokrasi rasional: melacak pemikiran Jürgen Habermas tentang ruang publik. Jurnal Ilmu Sosial dan Politik. 16. (2).

Ardianto, Elvinaro, Q-Anees. 2007. Filsafat ilmu komunikasi. Bandung: Simbiosa Rekama Media.

Armuji \& Pratikno. 2004. Konfigurasi kekuasaan elit lokal; dinamika ulama, Jawara, dan pengusaha di Kota Cilegon: Masa orde baru, masa transisi dan pasca reformasi tahun 2000 (Doctoral Dissertation, Universitas Gadjah Mada).

Asep, Kolopaking, Dharmawan. 2015. Dinamika peran sosial politik ulama dan Jawara di Pandeglang Banten. Jurnal Mimbar. 31(2).

Bandiyah. 2012. Evolusi Jawara di Banten (studi evolusi dari bandit menjadi pejabat. Jurnal Udaya. 9(3).

Denzin \& Lincoln. 2009. Handbook of qualitative research. Yogyakarta: Pustaka Pelajar

Fahmi Irfan. 2011. Jawara Banten. YPM Press Jakarta-Selatan.

Habermas J. 1984. The theory of communication action. (1): reason and the rationalization of society. Beacon Press. Boston Ma.

Habermas J. 1984. The theory of communicative action: a critique of fungionalist reason. Boston: Beacon Press.

Habermas J. 1987. The theory of communicative action (2): Lifeword and system: a critique of fugsionalist reason. Beacon Press Boston, Ma

Hamid A. 2011. Pergeseran peran kyai dalam politik di banten era orde baru dan reformasi. Jurnal Al Qalam. 28(2).

Hidayat S. 2007. Too much too soon. Local state elites perspective on and the puzzle of contemporary Indonesian regional autonomy policy. Rajagrafindo Jakarta.

Hopkins, R. 2008. What Do We See in Film? The Journal of Aesthetics and Art Criticism, Vol. 66 No. 2 Spring 2008. The American Society for Aesthetics. Washington.

Hudaeri, Mohamad. Tasbih dan golok: studi tentang kharisma kyai \& Jawara di Banten. Jurnal Istiqro. 2(1).

Kartodirdjo, Sartono. 1984. Pemberontakan petani Banten 1888. Jakarta: Pustaka Jaya.

Karomani, 2008. Komunikasi elite lokal di banten selatan (studi tentang persepsi dan pengelolaan kesan Jawara terhadap ulama dan umaro). Jurnal Sosiohumaniora. 10(1).

Karomani. 2017. Ulama, Jawara, dan umaro: studi tentang elite lokal di Banten. Sosiohumaniora. 1(2).

Kolopaking Lala M. 2011. Konflik dan potensi konflik di pedesaan. Bogor: Bahan kuliah sosiologi pedesaan (tidak dipublikasikan).

Nurdholt, HS dan Klinken (ed). 2007. Politik lokal di Indonesia. Jakarta. Yayasan Obor Indonesia.

Rusadi. 2014. Makna dan model komunikasi pembangunan. Jurnal Studi Komunikasi dan Media. 18(1) (2014):

Sjaf, S. 2014. Politik Etnik: Dinamika lokal di Kendari. Yayasan Pustaka Obor Indonesia.

Servaes J. 2002. Communication for development: One world, Multiple Culture, Second Printing. New Jersey (US): Hamptom Press, Inc.

Sujarwoto. 2015. Desentralisasi, dinasti politik dan kemiskinan di indonesia. tulisan ini menelaah hubungan desentralisasi, dinasti politik dan kemiskinan di Indonesia. JIAP. 1(2).

Sujatmiko, Iwan Gardono. 2006. Gerakan sosial dalam dinamikamasyarakat, dalam buku: gerakan sosial: 
e-ISSN: 2686-0724 - p-ISSN: 0853-4470 - Vol. 02, No. 02 (2019), pp. 104-116 wahana civil society bagi demokrasi. Editor: Darmawan Triwibowo LP3ES Indonesia

Sutisna, A. 2016. Gejala proliferasi dinasti politik di Banten era kepemimpinan gubernur Ratu Atut Chosiyah. Jurnal Politik Indonesia. 2(2).

Syarief Hidayat, 2007. Shadow state...? bisnis dan politik di provinsi Banten: Politik Lokal Di Indonesia. KITLV Jakarta.

Timmer. Jaap. 2005. Melanesia and review: isues and events, 2004-Papua. The contemporary pacific. $16: 442-56$ 